\title{
ABILITY OF AMILOLYTIC BACTERIA (Bacillus paramycoides AND Enterobacter cloacae) IN DEGRADING ORGANIC MATERIALS OF MANGROVE LITTLE
}

\author{
Redila Aprilivia Putri ${ }^{1 *}$, Nursyirwani ${ }^{1}$, Feliatra $^{1}$ \\ ${ }^{1}$ Department of Marine Science, Faculty of Fisheries and Marine Universitas Riau, Pekanbaru \\ *redilaapril@gmail.com
}

\begin{abstract}
This study aims to find out that Bacillus paramycoides and Enterobacter cloacae bacteria can produce amylase enzymes and have the ability to degrade organic matter, especially mangrove litter. From this study it was found that the optimal growth of B.paramycoides and E. cloacae bacteria occurred at $12^{\text {th }}$ hour. The results of measurements and calculations of absorbance values at $63010.238 \times 10^{8}$ cells $/ \mathrm{mL}$ (B. paramycoides) and $12.030 \times 10^{8}$ cells $/ \mathrm{mL}$ (E. cloacae) using the spectrophotometric method. Meanwhile, with the TPC method at 12 hours, the number of bacterial cells was $2.08 \times 10^{8} \mathrm{CFU} / \mathrm{s} / \mathrm{mL}$ (B.paramycoides) and $2.44 \times 10^{8} \mathrm{CFU}$ 's/mL (E. cloacae). The ability to produce the largest amylolytic bacterial amylase enzyme also occurred at 12 hours as much as $0.306 \mathrm{mg} / \mathrm{mL}$ (B.paramycoides) with an increase of $0.046 \mathrm{mg} / \mathrm{mL}$ and $0.243 \mathrm{mg} / \mathrm{mL}$ (E. cloacae) with an increase of $0.028 \mathrm{mg} / \mathrm{mL}$. The bacteria that have the highest amylase enzyme ability is E.cloacae as evidenced by the diameter of the clear zone of $10.10 \mathrm{~mm}$. Testing the ability of amylolytic bacteria in degrading mangrove litter was carried out by adding amylase enzyme as much as $0 \%, 50 \%$ and $100 \%$. Amylolytic bacteria can degrade organic matter by hydrolyzing starch contained in mangrove litter. The most degraded starch content was in the $100 \%$ enzyme treatment, which was $1.021 \mathrm{mg} / \mathrm{mL}$ (B. paramycoides) and $1.189 \mathrm{mg} / \mathrm{mL}$ (E.cloacae).
\end{abstract}

Keywords: Enzyme, Bacillus, Enterobacter, Degradation, Starch

\section{PENDAHULUAN}

Bakteri amilolitik dalam tanah mangrove berperan penting dalam proses degradasi amilum menjadi senyawa yang lebih sederhana dan menjadi nutrisi dalam tanah [1]. Bakteri amilolitik merupakan bakteri yang dapat menghasilkan enzim amilase yang mampu memecah pati menjadi glukosa [2]. Proses tersebut dapat berlangsung apabila terjadi kontak langsung antara sel bakteri dengan substrat.

Penelitian yang berkaitan tentang mikroorganisme khususnya bakteri yang berasal dari sedimen ekosistem mangrove di Indonesia masih jarang dilakukan, sehingga perlu dilakukan eksplorasi untuk menemukan bakteri yang mampu memproduksi enzim. Pada penelitian sebelumnya telah ditemukan jenis bakteri amilolitik dari sedimen ekosistem mangrove Stasiun Kelautan Dumai. Jenis bakteri amiloitik yang ditemukan antara lain Bacillus paramycoides (kode isolat TR6), Enterobacter cloacae (kode isolat TR 11) [3]. Namun, bakteri bakteri yang ditemukan tersebut masih belum diketahui kemampuannya dalam mendegradasi bahan organik khususnya serasah mangrove, oleh karena itu, adanya penelitian ini adalah bertujuan untuk mengetahui kemampuan 
bakteri amilolitik yang diisolasi dari sedimen ekosistem mangrove Stasiun Kelautan Dumai dalam mendegradasi serasah mangrove. Dengan sampel serasah yang diambil dari area hutan mangrove di Muala Sungai Dumai.

\section{METODE PENELITIAN}

\section{Waktu dan Tempat}

Penelitian ini dilaksanakan pada bulan bulan Agustus 2020. Uji kemampuan degradasi oleh bakteri amilolitik dilakukan di Laboratorium Mikrobiologi Laut Jurusan Ilmu Kelautan Fakultas Perikanan dan Kelautan Universitas Riau. Pengambilan serasah mangrove dilakukan di area Hutan Mangrove Stasiun Kelautan Dumai.

\section{Metode Penelitian}

Metode yang digunakan dalam penelitian ini adalah metode eksperimen, yaitu menguji kemampuan bakteri amilolitik serta pengaruh perbedaan konsentrasi enzim amilase yang digunakan dalam mendegradasi bahan organik serasah mangrove. Isolat bakteri yang digunakan dalam penelitian ini ada dua, yaitu isolat bakteri Bacillus paramycoides (TR6) dan Enterobacter cloacae (TR11) dengan tiga kali pengulangan dan dua konsentrasi enzim amilase yang diberikan yaitu $50 \%$ dan $100 \%$. Rancangan percobaan yang digunakan adalah rancangan acak lengkap satu faktor.

\section{Prosedur Penelitian}

\section{Peremajaan Isolat Bakteri}

Bakteri yang digunakan pada penelitian ini adalah bakteri yang telah diisolasi dari Sedimen Ekosistem Mangrove Stasiun Kelautan Purnama Dumai dan telah diidentifikasi secara molekuler berdasarkan penelitian sebelumnya [3]. Jenis bakteri yang digunakan adalah ada 2 yaitu isolat bakteri Bacillus paramycoides (TR6) dan Enterobacter cloacae (TR11). Isolat bakteri amilolitik diremajakan berdasarkan prosedur dari [4] yaitu dengan cara memindah ulang isolat ke dalam medium agar miring Marine Agar Zobell dengan menambahkan amilum $1 \%$ steril secara aseptis dengan jarum ose kemudian diinkubasi pada suhu $30^{\circ} \mathrm{C}$ selama $2 \times 24$ jam.

\section{Persiapan Bakteri Uji}

Pembuatan suspensi bakteri dilakukan dengan mengambil 6-7 ose bakteri dari hasil peremajaan dan dimasukkan ke dalam botol berisi akuades sebanyak $100 \mathrm{~mL}$ yang telah disterilkan. Kemudian larutan berisi bakteri tersebut divorteks sampai terbentuk suspensi lalu dibandingkan dengan larutan Mc.Farland 0,5 standard.

Suspensi dari Isolat bakteri yang terbentuk kemudian diambil sebanyak 10 $\mathrm{mL}$ ke dalam media TSB (Tryptic Soy Broth) yang telah ditambahkan amilum 1\% steril sebagai media pertumbuhan bakteri kemudian divorteks sampai homogen. Isolat tersebut kemudian dinkubasi selama 24 jam dalam shaker bath. Pengamatan pertumbuhan bakteri dan produksi enzim dilakukan setiap enam jam sekali.

\section{Penentuan Waktu Optimum Produksi Enzim Amilase}

Pengamatan uji penentuan waktu optimum produksi enzim amilase dilakukan 6 jam sekali selama 24 jam. Prosedur yang digunakan dalam penelitian ini adalah dengan cara mengambil masing masing 1 $\mathrm{mL}$ isolat bakteri kedalam mikro tub kemudian disentrifugasi selama 30 menit dengan kecepatan 9000 rpm. Dari hasil sentrifugasi tersebut akan terbentuk larutan enzim pada bagian atas tub sedangkan sel bakteri akan mengendap dibagian bawah. Larutan tersebut yang kemudian diambil menggunakan pipet tetes dan di masukkan kedalam kuvet untuk di amati absorbansinya menggunakan spektrofotometer dengan panjang gelombang 660 . 


\section{Penentuan Waktu Optimum Pertumbuhan Bakteri Amilolitik}

Uji penentuan waktu optimum pertumbuhan bakteri dilakukan dengan 2 tahap yaitu yang pertama adalah perhitungan jumlah koloni bakteri amilolitik dengan metode TPC (Total Plate Count) yaitu dengan mempersiapkan 5 botol tabung reaksi berisi $10 \mathrm{~mL}$ akuades steril. Sebanyak $1 \mathrm{~mL}$ isolat bakteri dimasukkan ke dalam tabung reaksi lalu divorteks prosedur tersebut diulangi sampai pengenceran $10^{-5}$. Pada pengenceran $10^{-5}$ diambil sebanyak $0,1 \mathrm{~mL}$ dan ditebarkan kedalam cawan petri berisi media PCA dan diratakan menggunakan batang L. Cawan tersebut dibungkus menggunakan plastic wrap dan diinkubasikan selama 24 jam untuk kemudian dihitung jumlah koloninya. Untuk perhitungan jumlah koloni bakteri menggunakan rumus [5]:

$$
\begin{aligned}
& \mathrm{CFU} / \mathrm{ml}=(\text { Jumlah Koloni/Faktor } \\
& \text { Pengenceran) } \quad \text { X (1/Faktor } \\
& \text { Pengenceran }\left(10^{1}\right) \text { ) }
\end{aligned}
$$

Untuk pengukuran pertumbuhan bakteri menggunakan spektrofotometer yang diawali dengan pembuatan blanko untuk menentukan panjang gelombang optimal. Pembuatan blanko menggunakan media TSB yang tidak berisi bakteri kemudian diukur absorbansinya dengan panjang gelombang 600-660 nm. Selanjutnya $5 \mathrm{ml}$ isolat bakteri diambil menggunakan spuit steril dan dimasukkan kedalam kuvet untuk dihitung absorbansinya menggunakan spektrofotometer dengan panjang gelombang yang telah ditentukan.

\section{Uji Enzim Amilase}

Uji amilase dilakukan dengan menginokulasikan isolat ke medium yang mengandung amilum dengan cara goresan. Setelah diinkubasi selama 24 jam pada suhu $30^{\circ} \mathrm{C}$ kemudian ditetesi reagen lugol's iodine. Amilase merupakan enzim yang mampu menghidrolisis molekul amilum menjadi glukosa atau oligo- sakarida. Dengan indikator larutan iodin tersebut akan memberikan warna bening yang menandakan bahwa isolat tersebut dapat menghidrolisis amilum. Adanya zona bening di sekitar koloni menunjukkan aktivitas enzim amilase.

\section{Uji Kemampuan Isolat Bakteri dalam mendegradasi Serasah Mangrove}

Uji kemampuan bakteri amilolitik dalam mendegradasi serasah mangrove dilakukan dengan cara $10 \mathrm{~g}$ serasah mangrove yang telah dihaluskan dan diayak diencerkan dengan menambahkan akuades sebanyak $100 \mathrm{~mL}$ kemudian ditambahkan enzim dari bakteri amilolitik, enzim amilase yang ditambahkan sebanyak $0 \%$, $50 \%$ dan $100 \%$. Pada uji ini dilakukan pengamatan kadar amilum pada awal inkubasi dan akhir inkubasi. Apabila bakteri dapat mendegradasi amilum maka kadar amilum akan berkurang selama proses berlangsung.

\section{Pengukuran Kadar Amilum}

Sebanyak $1 \mathrm{~mL}$ larutan pati dimasukkan ke dalam tabung reaksi dan ditambahkan dengan $3 \mathrm{~mL}$ pereaksi DNS, selanjutnya dipanaskan pada penangas air mendidih selama 5 menit kemudian didinginkan pada suhu ruang. Larutan dipindahkan ke dalam kuvet, absorbansi diukur pada panjang gelombang $550 \mathrm{~nm}$. Kadar gula ditentukan dengan menggunakan persamaan regresi absorbansi larutan standar.

Pengujian kandungan amilum dilakukan dengan mengambil $1 \mathrm{~mL}$ sampel serasah mangrove dengan perlakuan penambahan enzim amilase $0 \%, 50 \%$ dan $100 \%$ dan diinkubasi selama 60 menit kedalam tabung, kemudian ditambahkan 1 $\mathrm{mL}$ reagen DNS dan $2 \mathrm{ml}$ aquades. Tabung reaksi dipanaskan di dalam water bath selama 5 menit agar terjadi reaksi antara glukosa dengan DNS. Absorbansi tiap larutan diukur menggunakan spektro- 
fotometer dengan panjang gelombang 550 $\mathrm{nm}[6]$.

\section{Analisis Data}

Data laju degradasi bahan organik serasah mangrove oleh bakteri amilolitik disajikan dalam bentuk gambar dan tabel. Kemudian data tersebut dijelaskan secara deskriptif berdasarkan literatur terkait dengan penelitian ini. Untuk mengetahui kemampuan isolat bakteri dalam mendegradasi bahan organik digunakan uji ANOVA.

\section{HASIL DAN PEMBAHASAN Pertumbuhan Bakteri Amilolitik}

Bakteri amilolitik B. paramycoides (TR6) dan E. cloacae (TR11) diinkubasi selama 24 jam diamati pertumbuhannya setiap 6 jam sekali menggunakan metode spektrofotometri dan metode Total Plate Count (TPC). Hasil dari nilai absorbansi pertumbuhan bakteri dan perhitungan jumlah koloni (TPC) kedua bakteri tersebut kemudian dikonversikan dengan menggunakan rumus regresi linier $\mathrm{y}=\mathrm{ax}-\mathrm{b}$ yang didapat dari nilai kurva standar Mc.farland 0,5 sehingga didapatkan hasil seperti pada Tabel 1 dan Tabel 2.

Tabel 1. Jumlah Bakteri Amilolitik dari Hasil Perhitungan dengan Metode Spektrofotometri.

\begin{tabular}{cccccc}
\hline Isolat & \multicolumn{5}{c}{ Jumlah sel bakteri per jam $(\mathbf{x ~ 1 0}$ sel/mL) } \\
\cline { 2 - 6 } Bakteri & $\mathbf{0}$ & $\mathbf{6}$ & $\mathbf{1 2}$ & $\mathbf{1 8}$ & $\mathbf{2 4}$ \\
\hline TR6 & $0,312 \pm 0,296$ & $4,801 \pm 0,160$ & $10,248 \pm 0,154$ & $11,687 \pm 0,089$ & $12,047 \pm 0,051$ \\
TR11 & $2,017 \pm 0,219$ & $5,829 \pm 1,789$ & $12,030 \pm 0,030$ & $12,201 \pm 0,154$ & $12,407 \pm 0,089$ \\
\hline
\end{tabular}

Tabel 2. Perhitungan Jumlah Sel Bakteri Amilolitik dengan Metode TPC

\begin{tabular}{cccccc}
\hline Kode & \multicolumn{5}{c}{ Jumlah sel bakteri per jam $\left(\times \mathbf{1 0}^{\mathbf{8}} \mathbf{C F U} / \mathbf{m L}\right)$} \\
\cline { 2 - 6 } Bakteri & $\mathbf{0}$ & $\mathbf{6}$ & $\mathbf{1 2}$ & $\mathbf{1 8}$ & $\mathbf{2 4}$ \\
\hline TR6 & $1,14 \pm 0,015$ & $1,56 \pm 0,031$ & $2,08 \pm 0,126$ & $1,88 \pm 0,127$ & $1,97 \pm 0,205$ \\
TR11 & $1,25 \pm 0,113$ & $1,59 \pm 0,24$ & $2,44 \pm 0,274$ & $2,02 \pm 0,185$ & $1,76 \pm 0,157$ \\
\hline
\end{tabular}

Keterangan: TR $6:$ B. paramycoides; TR11 : E. cloacae

Tabel 1 tersebut diketahui bahwa puncak pertumbuhan bakteri amilolitik terjadi pada jam ke 12 yaitu B.paramycoides (TR6) mengalami pertumbuhan sel sebanyak $10.238 \times 10^{8}$ sel/mL dan E. cloacae (TR11) mengalami pertumbuhan sel sebanyak $12,030 \times 10^{8}$ $\mathrm{sel} / \mathrm{mL}$. Fase logaritmik ini disebabkan pembelahan bakteri yang meningkat karena telah beradaptasi dengan lingkungannya serta nutrisi yang terdapat di dalam medium mencukupi bagi bakteri [7]. Menurut [8] fase logaritmik menggambarkan sel membelah diri dengan laju yang konstan, masa menjadi dua kali lipat dengan laju sama dan aktivitas metabolisme konstan. Fase logaritmik menggambarkan sel membelah diri dengan laju yang konstan, masa menjadi dua kali lipat dengan laju sama, aktifitas metabolisme konstan, serta keadaan pertumbuhan seimbang. Menurut [9] kecepatan pertumbuhan pada fase ini sangat dipengaruhi oleh media tempat tumbuhnya seperti $\mathrm{pH}$ dan kandungan nutrien, juga kondisi lingkungan termasuk suhu serta kelembaban udara.

Tabel 2 diketahui waktu optimal pertumbuhan bakteri amilolitik yang dianalisis dengan metode TPC terjadi pada jam ke 12 yaitu dengan jumlah koloni $B$. paramycoides sebanyak $2,08 \times 10^{8} \mathrm{CFU}$ 's/ $\mathrm{mL}$ dan E. cloacae sebanyak $2,44 \times 10^{8}$ CFU's/mL.

\section{Uji Aktivitas Enzim Amilase}

Pengujian enzim amilase dilakukan dengan mengamati zona bening yang terbentuk pada media agar dengan penambahan pati yang telah diinokulasikan oleh bakteri $B$. paramycoides (TR6) dan 
E.cloacae (TR11). Dari hasil percobaan tersebut diketahui bahwa bakteri mampu memproduksi enzim amilase dibuktikan dengan adanya zona bening yang terbentuk oleh bakteri $B$. paramycoides sebesar 9.03 mm dan bakteri E. cloacae memiliki zona bening sebesar $10.10 \mathrm{~mm}$ atau dapat dilihat pada Tabel 3.

Tabel 3. Diameter Zona Bening yang dihasilkan Bakteri Amilolitik (mm)

\begin{tabular}{ccccc}
\hline \multirow{2}{*}{ Kode Isolat } & \multicolumn{3}{c}{ Pengulangan } & Rata Rata \\
\cline { 2 - 4 } & $\mathbf{1}$ & $\mathbf{2}$ & $\mathbf{3}$ & $(\mathbf{m m})$ \\
\hline B. paramycoides (TR6) & 10,30 & 9,60 & 7,20 & 9,03 \\
E. cloacae (TR11) & 8,60 & 11,00 & 10,70 & 10,10 \\
\hline
\end{tabular}

Bakteri B. paramycoides dan E.cloacae dapat dikatakan memiliki daya amilolitik. berdasarkan pernyataan [10] bahwa isolat bakteri yang menghasilkan diameter zona bening dua atau tiga kali diameter koloni merupakan produsen enzim yang potensial. Aktivitas amilase ditentukan berdasarkan zona bening yang terbentuk pada medium yang telah ditambahkan larutan reagen lugol's iodine. Bakteri yang memiliki aktivitas enzim amilase ekstraseluler dapat menghidrolisis pati (amilosa dan amilopektin) yang terkandung dalam medium agar sehingga pati yang telah terdegradasi tidak dapat berikatan dengan iodin $\left(\mathrm{I}^{2}\right)$ dan menghasilkan zona bening di sekeliling koloni bakteri. Daerah yang patinya belum terhidrolisis akan berwarna biru ungu dikarenakan adanya ikatan antara pati dengan iodin [11].

\section{Produksi Enzim Amilase Bakteri Amilolitik}

Hasil pengukuran produksi enzim kasar amilase oleh isolat bakteri amilolitik dikonversikan menggunakan rumus regresi linear $\mathrm{y}=\mathrm{ax}+\mathrm{b}$ yang didapat dari kurva standar DNS. Hasil konversi dari pengukuran absorbansi tersebut dapat dilihat pada Tabel 4.

Tabel 4. Konsentrasi Enzim Amilase dalam Ekstrak Sel Bakteri (mg/mL)

\begin{tabular}{|c|c|c|c|c|c|}
\hline \multirow{2}{*}{ Isolat Bakteri } & \multicolumn{5}{|c|}{ 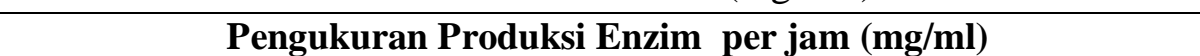 } \\
\hline & $\mathbf{0}$ & 6 & 12 & 18 & 24 \\
\hline TR6 & $0,202 \pm 0,008$ & $0,260 \pm 0,008$ & $0,306 \pm 0,019$ & $0,244 \pm 0,004$ & $0,230 \pm 0,018$ \\
\hline Peningkatan & 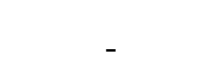 & 0,058 & 0,046 & $-0,062$ & $-0,014$ \\
\hline TR11 & $0,205 \pm 0,005$ & $0,215 \pm 0,005$ & $0,243 \pm 0,009$ & $0,224 \pm 0,022$ & $0,215 \pm 0,008$ \\
\hline $\begin{array}{c}\text { Peningkatan } \\
\text { Produksi Enzim }\end{array}$ & - & 0,01 & 0,028 & $-0,019$ & 0,009 \\
\hline
\end{tabular}

Berdasarkan penelitian [12] tentang karakterisasi enzim amilase dari bakteri B.megaterium pada variasi suhu, $\mathrm{pH}$ dan konsentrasi substrat, dari hasil penelitian tersebut didapatkan hasil bahwa suhu optimum bakteri B.megaterium dalam memproduksi enzim amilase pada suhu $37^{\circ} \mathrm{C}$ dengan aktivitas amilase sebesar $1,279 \mathrm{U} / \mathrm{mL}$. Karakterisasi enzim yang kedua, dilihat dari $\mathrm{pH}$ optimum bakteri dalam memproduksi enzim amilase, didapatkan hasil bahwa $\mathrm{pH}$ optimum bakteri $B$. megaterium dalam memproduksi enzim amilase yakni pada $\mathrm{pH}$ 5,0 dengan aktivitas enzim sebesar 1,241 U/mL. Karakterisasi enzim yang ketiga, dilihat dari konsentrasi substrat optimum bakteri dalam memproduksi enzim amilase didapatkan hasil bahwa konsentrasi substrat $1,50 \%$ menjadi konsentrasi substrat yang optimum dengan aktivitas enzim amilase sebesar 0,548 U/mL. Enzim amilase yang 
dihasilkan oleh bakteri B. Paramycoides dan E. Cloacae relatif lebih sedikit dikarenakan tidak adanya perlakuan kontrol terhadap $\mathrm{pH}$ maupun suhu dan konsentrasi substrat. Selain itu waktu optimal pertumbuhan bakteri juga mempengaruhi jumlah enzim yang dihasilkan.

Enzim amilase yang dihasilkan oleh bakteri $B$. paramycoides dan E. cloacae relatif lebih sedikit dikarenakan tidak adanya perlakuan kontrol terhadap $\mathrm{pH}$ maupun suhu dan konsentrasi substrat. Pada penelitian oleh [12] pengamatan aktivitas enzim selama 140 jam sedangkan penelitian ini hanya selama 24 jam karena adanya keterbatasan waktu.

\section{Kemampuan Bakteri Amilolitik dalam Mendegradasi Serasah Mangrove}

Hasil dari nilai absorbansi amilum yang didapatkan kemudian dikonversikan menggunakan rumus regresi linear $\mathrm{y}=\mathrm{ax}+\mathrm{b}$ yang didapat dari kurva standar DNS dan hasil dari konversi tersebut dapat dilihat pada Tabel 5.

Tabel 5. Hasil Pengukuran Amilum Terlarut Serasah Mangrove

\begin{tabular}{|c|c|c|c|}
\hline Kode Bakteri & Dosis Enzim & Ulangan & Kadar Amilum (mg/mL) \\
\hline \multirow{12}{*}{ TR6 } & \multirow{4}{*}{$0 \%$} & 1 & 1,719 \\
\hline & & 2 & 1,603 \\
\hline & & 3 & 1,483 \\
\hline & & Rata rata & 1,602 \\
\hline & \multirow{4}{*}{$50 \%$} & 1 & 1,231 \\
\hline & & 2 & 1,330 \\
\hline & & 3 & 1,208 \\
\hline & & Rata rata & 1,256 \\
\hline & \multirow{4}{*}{$100 \%$} & 1 & 1,062 \\
\hline & & 2 & 0,971 \\
\hline & & 3 & 1,030 \\
\hline & & Rata rata & 1,021 \\
\hline \multirow{8}{*}{ TR11 } & \multirow{4}{*}{$50 \%$} & 1 & 1,335 \\
\hline & & 2 & 1,272 \\
\hline & & 3 & 1,230 \\
\hline & & Rata rata & 1,279 \\
\hline & \multirow{4}{*}{$100 \%$} & 1 & 1,235 \\
\hline & & 2 & 1,086 \\
\hline & & 3 & 1,244 \\
\hline & & Rata rata & 1,189 \\
\hline
\end{tabular}

Berdasarkan Tabel 5 dapat dilihat bahwa kadar amilum yang terdegradasi paling banyak adalah pada perlakuan enzim sebanyak $100 \%$ yaitu dengan amilum yang tersisa pada sampel adalah sebesar 1.021 $\mathrm{mg} / \mathrm{mL}$ (B. paramycoides) dan 1.189 $\mathrm{mg} / \mathrm{mL}$ (E.cloacae). Berdasarkan penelitian [13] tentang analisis unsur hara dan kandungan proksimat pada detritus mangrove, mangrove jenis $S$. alba dan $R$. apiculata memiliki kandungan karbohidrat sebanyak masing masing $7,08 \%$ dan $6,27 \%$.
Enzim amilase pada bakteri terdiri dari $\alpha$-amilase, yang berfungsi memutus ikatan glukosil, memproduksi gula yang berukuran kecil dekstrin dengan glukosa dan maltose [14]

\section{KESIMPULAN DAN SARAN Kesimpulan}

Waktu optimal produksi enzim amilase oleh bakteri amilolitik adalah pada jam ke 12 yaitu sebesar $0.306 \mathrm{mg} / \mathrm{mL}$ (B.paramycoides) dan $0.243 \mathrm{mg} / \mathrm{mL}$ (E.cloacae). Bakteri amilolitik dibuktikan 
dapat mendegradasi bahan organik dengan cara menghidrolisis amilum yang terdapat dalam serasah mangrove. Kadar amilum yang terdegradasi paling banyak adalah pada perlakuan enzim sebanyak $100 \%$ yaitu sebanyak $1.021 \mathrm{mg} / \mathrm{mL}$ (B. paramycoides) dan $1.189 \mathrm{mg} / \mathrm{mL}$ (E. cloacae).

\section{Saran}

Adapun saran dari penelitian ini yaitu sebaiknya dilakukan pengujian pertumbuhan dan produksi enzim bakteri amilolitik berdasarkan variasi suhu dan $\mathrm{pH}$ dan pengujian kemampuan bakteri amilolitik dalam mendegradasi bahan lain, seperti misalnya limbah organik.

\section{DAFTAR PUSTAKA}

1. Hastuti, U.S., S.A.N. Febriani dan M.A.A. Putri. (2017). Isolasi dan Identifikasi Spesies Bakteri Amilolitik yang Berasal dari Tanah Mangrove di Margomulyo, Balikpapan, Kalimantan Timur. Prosiding Seminar Nasional III.

2. Murtius, W.S. (2016). Aktivitas amilolitik pada Parutan Ubi Kayu (Manihot uttilissima) yang Diperam dengan Waktu yang Berbeda. Jurusan Teknologi Pertanian Andalas, 20(1) : 1410-1920

3. Silitonga, L.R., Nursyirwani, dan I. Effendi. (2020). Isolation, Identification and Sensivitity of Amilolitic Bacteria from Mangrove Ecosystem Sediment in Purnama Marine Station Dumai on the Pathogenic Bacteria. Asian Journal of Aquatic Sciences, 2(3): 257-266

4. Ningsih, D.R., U. Rastuti dan R. Kamaludin. (2012). Karakterisasi Enzim Amilase dari Bakteri Bacillus amyloliquefaciens. Prosiding Seminar Nasional. UNSOED. Purwokerto. 39-45.

5. Sukmawati., Ratna dan A. Fahrizal. (2018). Analisis Cemaran Mikroba pada Daging Ayam Broiler di Kota Makassar. Jurnal Scripta Biologica, 5(1): 68-71.

6. Julaeha, E., S. Rustiyaty., N. N. Fajri., F. Ramdlan dan R. Tantra. (2016). Pemanfaatan Tepung Gadung (Dioscorea hispida Dennst.) pada Produksi Amilase Menggunakan Bacillus Sp. E journal Universitas Pendidikan Indonesia, 1(1).

7. Oktavia, Y., S.D. Lestari., S. Lestari., Herpandi dan M. Jannah. (2018). Optimasi Waktu Inkubasi Produksi Protease dan Amilase Isolat Bakteri Asal Terasi Ikan Teri Stolephorus sp. Jurnal Ilmu dan Teknologi Kelautan Tropis, 10(3) : 719-725.

8. Reiny, S.S. (2012). Potensi Lactobacillus acidophilus ATCC 4796 sebagai Biopreservatif Pada Rebusan Daging Ikan Tongkol. J. IJAS, 2(2): 604-613.

9. Setyati, W. A., E. Martani., T. Subagiyo dan M. Zainuddin. (2015). Kinetika Pertumbuhan dan Aktivitas Protease Isolat 36k dari Sedimen Ekosistem Mangrove, Karimunjawa, Jepara. Jurnal Ilmu Kelautan, 20(3): 163- 169.

10. Ochoa-Solano, J., and J. Olmos-Soto. (2006). The Functional Property of Bacillus for Shrimp Feeds. Food Microbiology, 23: 519-525.

11. Zahidah, D., dan M. Shovitri. (2013). Isolasi, Karakterisasi dan Potensi Bakteri Aerob Sebagai Pendegradasi Limbah Organik. Jurnal Sains dan Seni POMITS, 2(1) : 23373520

12. Istia'nah, D., U. Utami dan A. Barizi. (2020). Karakterisasi Enzim Amilase dari Bakteri Bacillus megaterium pada Variasi Suhu, pH dan Konsentrasi Substrat. Jurnal Riset Biologi dan Aplikasinya, 2(1).

13. Faldin., A. I. Nur dan M. Ramli. (2016). Studi Kualitas Detritus pada Jenis Mangrove Rhizophora apiculata dan Sonneratia alba di Kelurahan Lalowaru, Kecamatan Moramo Utara, Kabupaten Konawe Selatan. Jurnal Manajemen Sumber Daya Perairan, 2(1): 51-61 
14. Andry, M. P. U dan M. Shovitri. (2014). Bakteri Tanah Pendegradasi Bahan Organik Desa Talango Pulau Poteran Sumenep. Jurnal Sains dan Seni Pomits, 3(2). 